Du, D.-H., Tang, M., Li, W., Kay, S.M., and Wang, X.-L., 2022, What drives Fe depletion in calc-alkaline magma differentiation: Insights from Fe isotopes: Geology, https://doi.org/10.1130/G49705.1

SUPPLEMENTAL MATERIAL for:

\title{
What drives Fe depletion in calc-alkaline magma differentiation: insights from $\mathrm{Fe}$ isotopes
}

De-Hong Du', Ming Tang², Weiqiang Li ${ }^{1}$, Suzanne Mahlburg Kay ${ }^{3}$, Xiao-Lei

Wang $^{1^{*}}$

${ }^{1}$ State Key Laboratory for Mineral Deposits Research, School of Earth Sciences and

Engineering, Nanjing University, Nanjing 210023, China

${ }^{2}$ Key Laboratory of Orogenic Belt and Crustal Evolution, MOE; School of Earth and

Space Sciences, Peking University, Beijing 100871, China

${ }^{3}$ Department of Earth and Atmospheric Sciences, Cornell University, Ithaca, NY

14850, USA

*E-mail: wxl@nju.edu.cn (XL Wang); 


\section{Analytical Method}

The $\mathrm{Fe}$ isotope compositions of the whole-rock samples were measured at State Key Laboratory for Mineral Deposits Research, Nanjing University, China. The purification and analytical methods have been described in detail by Du et al. (2017) and Ye et al. (2017). Briefly, $\sim 20 \mathrm{mg}$ of sample powder was dissolved in Teflon beakers using a 2:1:1 mixture of concentrated $\mathrm{HCl}-\mathrm{HNO}_{3}-\mathrm{HF}$ on a hotplate for two days. The digested samples were purified using ion-exchange chemistry with a chloride-form AG MP-1 anion-exchange resin. The resulting purified $\mathrm{Fe}$ solutions were measured using multicollector-inductively coupled plasma-mass spectrometry (MC-ICP-MS) employing a Thermo Fisher Scientific Neptune Plus instrument with moderate resolution and used in the wet-plasma mode. The resulting sensitivity was $6-10 \mathrm{~V} / \mathrm{ppm}$ for ${ }^{56} \mathrm{Fe}$, with a $2 \mathrm{ppm}$ Fe solution used during analysis. A standard-sample-standard bracketing method was used to correct for mass bias and instrument drift, and iron isotope compositions are reported as the per mil deviation $\left(\delta^{56} \mathrm{Fe}\right)$ from the international standard IRMM-014 $\left(\delta^{56} \mathrm{Fe}_{\text {sample }}=\left[\left({ }^{56} \mathrm{Fe} /{ }^{54} \mathrm{Fe}\right)_{\text {sample }} /\left({ }^{56} \mathrm{Fe} /{ }^{54} \mathrm{Fe}\right)_{\text {IRMM-014 }}-1\right] \times 1000\right.$ [\%o]). Analytical reproducibility on $\delta^{56} \mathrm{Fe}$ is better than $\pm 0.06 \%$ ( 2 standard deviations, 2SD) based on repeated analyses of several international standards against an in-house stock solution (Du et al., 2017; Ye et al., 2017; Huang et al., 2021). The measured GSP-2 and w-2a geological standards, which were purified and measured together with samples in this study, yield $\delta^{56} \mathrm{Fe}$ values of $0.16 \pm 0.04 \%$ o $\left(\delta^{57} \mathrm{Fe}=0.20 \pm 0.09 \%, \mathrm{n}=4,2 \mathrm{SD}\right)$ and $0.07 \pm 0.04 \%$ o $\left(\delta^{57} \mathrm{Fe}=0.10 \pm\right.$ $0.13 \%, \mathrm{n}=6,2 \mathrm{SD}$ ), consistent with the published values (e.g., Craddock and Dauphas, 2011; He et al., 2015). In addition, $\delta^{56} \mathrm{Fe}$ of two ultrapure Fe solutions, J-M and HPS Fe, are $0.34 \pm$ $0.04 \%$ o $\left(\delta^{57} \mathrm{Fe}=0.51 \pm 0.08 \%, \mathrm{n}=5,2 \mathrm{SD}\right)$ and $0.59 \pm 0.06 \%$ o $\left(\delta^{57} \mathrm{Fe}=0.84 \pm 0.15 \%, \mathrm{n}=5\right.$, 2SD), which are also in excellent agreements with the recommended values (Beard et al., 2003; Heimann et al., 2008). For the samples investigated in this study, each sample was measured at least three times, and analytical uncertainties of $\mathrm{Fe}$ isotope ratios were given as $2 \mathrm{SD}$. The uncertainties on $\delta^{57} \mathrm{Fe}$ are much higher than those on $\delta^{56} \mathrm{Fe}$. This is due to the limitation of counting statistics of low signal of ${ }^{57} \mathrm{Fe}(<0.3 \mathrm{~V}$ for typical session). 


\section{Crystal fractionation modelling based on pMELTS}

In order to evaluate the role of pressure (crustal thickness) on Fe isotope fractionation and trace-element (i.e., $\mathrm{Sm} / \mathrm{Yb}$ ratio) evolution of arc magmas, we use pMELTS program (Ghiorso et al., 2002) to predict how residual melt and complementary cumulate relate in equilibrium for a range of pressures $(0.2-2.0 \mathrm{GPa}$, the pressure step was set as $0.1 \mathrm{GPa})$ and oxygen fugacities (from QFM - 1 to QFM + 1). A primitive arc magma from Andean CVZ, defined by Schmidt and Jagoutz (2017), was used as the starting composition, i.e., AN-73 (volatile-free): $53.82 \mathrm{wt} \%$ $\mathrm{SiO}_{2}, 1.18 \mathrm{wt} \% \mathrm{TiO}_{2}, 15.88 \mathrm{wt} \% \mathrm{Al}_{2} \mathrm{O}_{3}, 7.68$ wt $\% \mathrm{FeO}_{\mathrm{T}}, 0.13 \mathrm{wt} \% \mathrm{MnO}, 8.24 \mathrm{wt} \% \mathrm{MgO}, 8.29$ wt $\% \mathrm{CaO}, 2.78 \mathrm{wt} \% \mathrm{Na}_{2} \mathrm{O}, 1.71 \mathrm{wt} \% \mathrm{~K}_{2} \mathrm{O}$, and $0.28 \mathrm{wt} \% \mathrm{P}_{2} \mathrm{O}_{5}$. For simplicity, we referred to 'Initial Composition A' for this primitive arc magma in the latter section. Initial water content was set as $3 \mathrm{wt} \%$. For comparison, we also tested a higher initial water content of $4 \mathrm{wt} \%$. Simulations were conducted for closed-system batch crystallization starting from the liquidus temperature and decreasing at $5{ }^{\circ} \mathrm{C}$ steps. At each step, the compositions and respective mass of residual melt and minerals in equilibrium were obtained.

With the coexisting mineral assemblages, we calculated the bulk $\mathrm{Sm}$ and $\mathrm{Yb}$ partition coefficients between minerals and melt based on the definition of a bulk partition coefficient:

$$
\mathrm{D}=x_{1} K d_{1}+x_{2} K d_{2}+x_{3} K d_{3} \ldots
$$

where $K d$ is the mineral/melt partition coefficient and $x_{i}$ refers to the mass fraction of a particular mineral out of the total crystallized assemblages. The partition coefficients for different minerals used in the modeling are given in Table S2. We then calculated the evolution of $\mathrm{Sm}$ and $\mathrm{Yb}$ in the evolving melt based on Rayleigh fractionation model, with $\mathrm{Sm}$ and $\mathrm{Yb}$ concentrations in evolving melt $(C)$ given as:

$$
\frac{C}{C_{0}}=F^{(D-1)}
$$

where $F$ is the mass fraction of residual melt, and $C_{0}$ is the initial concentrations of Sm and $\mathrm{Yb}$. We assumed that the initial melt has $\mathrm{Sm}$ and $\mathrm{Yb}$ concentrations of $4 \mathrm{ppm}$ and $2 \mathrm{ppm}$ (i.e., $\mathrm{Sm} / \mathrm{Yb}=2$ ), respectively.

The Fe isotope evolution of the melt $\left(\delta^{56} \mathrm{Fe}_{\text {melt }}\right)$ was calculated using the Rayleigh fractionation model:

$$
\delta^{56} F e_{\text {melt }}=\delta^{56} F e_{\text {initial }}+\Delta^{56} F e_{\text {crystals-melt }} \times \ln \left(f_{F e}\right)
$$


where the fraction of iron remaining in the melt is $f_{F e}=\frac{F \times C_{\text {melt }}^{F e O}}{C_{\text {inital }}^{F e O}}(F$ and $C$ refer to the melt fraction and $\mathrm{Fe}$ content, respectively), and $\Delta^{56} F e_{\text {crystals-melt }}$ is the fractionation factor between the residual melt and the minerals removed. The $\Delta^{56} \mathrm{Fe}_{\text {crystals-melt }}$ is obtained with the equation:

$$
\Delta^{56} \mathrm{Fe}_{\text {crystals-melt }}=\sum_{i}\left(\Delta^{56} \mathrm{~F} e_{\text {mineral-melt }}^{i} \times W^{i}\right)
$$

where $\Delta^{56} F e_{\text {mineral-melt }}^{i}$ is the fractionation factor between a specific mineral $i$ and the residual melt, and $W^{i}$ is the iron fraction of mineral $i$ to the bulk cumulate $\left(\sum_{i} W^{i}=1\right)$. The fractionation factors $\left(\Delta^{56} F e_{\text {mineral-melt }}^{i}\right)$ used in the modeling are listed in Table S1. The initial arc melt is assumed to have a $\delta^{56} \mathrm{Fe}$ value of $0.05 \%$.

In addition, another starting composition equivalent to an arc basalt from the Central Andes database (GEOROC) was also assumed (volatile-free; $51.17 \mathrm{wt} \% \mathrm{SiO}_{2}, 1.89 \mathrm{wt} \% \mathrm{TiO}_{2}, 15.49$ $\mathrm{wt} \% \mathrm{Al}_{2} \mathrm{O}_{3}, 9.00 \mathrm{wt} \% \mathrm{FeO}_{\mathrm{T}}, 0.15 \mathrm{wt} \% \mathrm{MnO}, 7.28 \mathrm{wt} \% \mathrm{MgO}, 8.12 \mathrm{wt} \% \mathrm{CaO}, 3.77 \mathrm{wt} \% \mathrm{Na}_{2} \mathrm{O}$, $2.11 \mathrm{wt} \% \mathrm{~K}_{2} \mathrm{O}$, and $0.82 \mathrm{wt} \% \mathrm{P}_{2} \mathrm{O}_{5}$ ). We referred to 'Initial Composition B' for this starting composition. The 'Initial Composition B' differs from 'Initial Composition A' with higher $\mathrm{FeO}_{\mathrm{T}}$ but lower $\mathrm{SiO}_{2}$ and $\mathrm{MgO}$ contents.

All the modeling studies are summarized below:

\begin{tabular}{|c|c|c|c|c|c|}
\hline Parental melt & Reference & $\begin{array}{c}\text { Initial } \mathrm{H}_{2} \mathrm{O} \\
\text { (wt } \%)\end{array}$ & $\mathrm{P}(\mathrm{GPa})$ & $f \mathrm{O}_{2}$ & Figure \\
\hline Initial Composition A & \multirow{4}{*}{$\begin{array}{l}\text { Schmidt and } \\
\text { Jagoutz } \\
\text { (2017) }\end{array}$} & 3 & $2-0.2$ & $\mathrm{QFM}+1$ & Fig. 3B, D \\
\hline Initial Composition A & & $3 \& 4$ & $2-0.2$ & $\mathrm{QFM}+1$ & Fig. S1 \\
\hline Initial Composition A & & $3 \& 4$ & $2-0.2$ & QFM & Fig. S2 \\
\hline Initial Composition A & & $3 \& 4$ & $2-0.2$ & QFM - 1 & Fig. S3 \\
\hline Initial Composition B & \multirow{3}{*}{$\begin{array}{c}\text { GEOROC } \\
\text { database }\end{array}$} & 3 & $2-0.2$ & $\mathrm{QFM}+1$ & Fig. S4 \\
\hline Initial Composition B & & 3 & $2-0.2$ & QFM & Fig. S5 \\
\hline Initial Composition B & & 3 & $2-0.2$ & QFM - 1 & Fig. S6 \\
\hline
\end{tabular}

These modeling results indicate that the arc magma $\delta^{56} \mathrm{Fe}$ gradually increases with increasing crustal thickness under more oxidized states (e.g., $\geq$ QFM), regardless of the starting compositions. 


\section{Interpretation of the high $\delta^{56} \mathrm{Fe}$ in the younger "Normal Crust" samples}

The younger "Normal Crust" samples $(18-10 \mathrm{Ma})$ have higher $\delta^{56} \mathrm{Fe}$ values than the older "Normal Crust" samples (> $19 \mathrm{Ma})$. All the "Normal Crust" samples have low and relatively homogeneous $\mathrm{Sm} / \mathrm{Yb}$ ratios, indicating they did not experience garnet fractionation. Four candidate mechanisms may explain the higher $\delta^{56} \mathrm{Fe}$ signatures of the younger "Normal Crust" samples: (1) higher degrees of magmatic differentiation; (2) similar degrees of differentiation at different in $\mathrm{fO}_{2}$ and water contents; (3) higher degrees of crustal contamination; or (4) $\mathrm{Fe}$ isotopically heavier sources. The younger and older samples are very similar in indexes of magma differentiation, including major (e.g., $\mathrm{SiO}_{2}, \mathrm{MgO}, \mathrm{FeO}$; Fig. $3 \mathrm{~A}$ ) and trace element indicators (e.g., Cr, Ni, La/Yb and $\mathrm{Sm} / \mathrm{Yb}$; Fig. 3B; Fig. S7A, B). These suggest that they experienced comparable extents of magma differentiation, eliminating mechanism (1). At low $\mathrm{fO}_{2}$ (i.e., QFM - 1) and low water content (e.g., $3 \mathrm{wt} \%$ ), clinopyroxene and olivine are the dominant Fe-bearing minerals under mediate to low pressures $(<\sim 25 \mathrm{~km})$, and fractionation of these two phases can increase $\delta^{56} \mathrm{Fe}$ in residual melts up to $\sim 0.13 \%$ o (at $50 \mathrm{wt} \%$ crystallinity; Fig. S3B, Fig. S6B), similar to those of the younger "Normal Crust" samples. However, fractionation of clinopyroxene and olivine cannot lead to clear Fe depletion (e.g., Sossi et al., 2012; Tang et al., 2018). Under hydrous (e.g., 4 wt\% initial water content) and oxidizing conditions, amphibole and magnetite fractionations can explain the moderate Fe depletion (e.g., Kay et al., 1991; Kay and Mpodozis, 2001; Zimmer et al., 2010), but they cannot produce the higher $\delta^{56} \mathrm{Fe}$ values (Fig. 1C). These indicate that mineral fractionation under low to mediate pressures (i.e., without garnet saturation) hardly explain simultaneous Fe depletion and high $\delta^{56} \mathrm{Fe}$ signatures of the younger "Normal Crust" magmas. Increasing crustal contamination should be reflected in the ratios such as $\mathrm{Th} / \mathrm{La}$ and $\mathrm{Ba} / \mathrm{Th}$ (Kay et al., 2013). However, the younger "Normal crust" samples have $\mathrm{Th} / \mathrm{La}$ and $\mathrm{Ba} / \mathrm{Th}$ ratios broadly identical to those of the older "Normal Crust" samples (Fig. S7C, D), indicating that crustal contamination is not responsible for the higher $\delta^{56} \mathrm{Fe}$ signatures.

Magma differentiation (i.e., partial melting and fractional crystallization) cannot explain the high $\delta^{56} \mathrm{Fe}$ values of the younger "Normal Crust" samples, and thus an additional contribution from some isotopically heavy materials is required, such as magnetite-bearing cumulates and 
metasomatized mantle peridotites. Magnetite-bearing cumulates formed via earlier arc magma differentiation tend to enrich in heavy Fe isotopes. To test this possibility, we calculated the $\delta^{56} \mathrm{Fe}$ evolution of cumulate based on pMELTS modeling results of hydrous basalt crystal fractionation under $0.2-2.0 \mathrm{GPa}, 3 \mathrm{wt} \%$ initial water content, and a constant $f_{2}$ of QFM +1 . As shown in Fig. S8, magnetite-bearing cumulates formed at $\sim 25-40 \mathrm{~km}$ depths have $\delta^{56} \mathrm{Fe}$ values ranging from $\sim 0.04 \%$ to $-0.02 \%$, slightly lower than the mean value of unmetasomatised upper mantle lherzolite $(0.033 \pm 0.01 \%$, 2SE; Sossi et al., 2016). Thus, incorporating of these magnetite-bearing cumulates into arc magmas and/or their sources cannot explain the high $\delta^{56} \mathrm{Fe}$ values of the "Normal Crust" samples. In addition, Weyer and Ionov (2007) indicated that the $\mathrm{Fe}$ isotope composition of mantle peridotites could be significantly modified by metasomatic processes (e.g., melt percolation), which lead to an increase in $\delta^{56} \mathrm{Fe}$ values up to $0.16 \%$. In this regard, metasomatized peridotites are the possible sources that elevate the $\delta^{56} \mathrm{Fe}$ values of the younger "Normal Crust" lavas. 

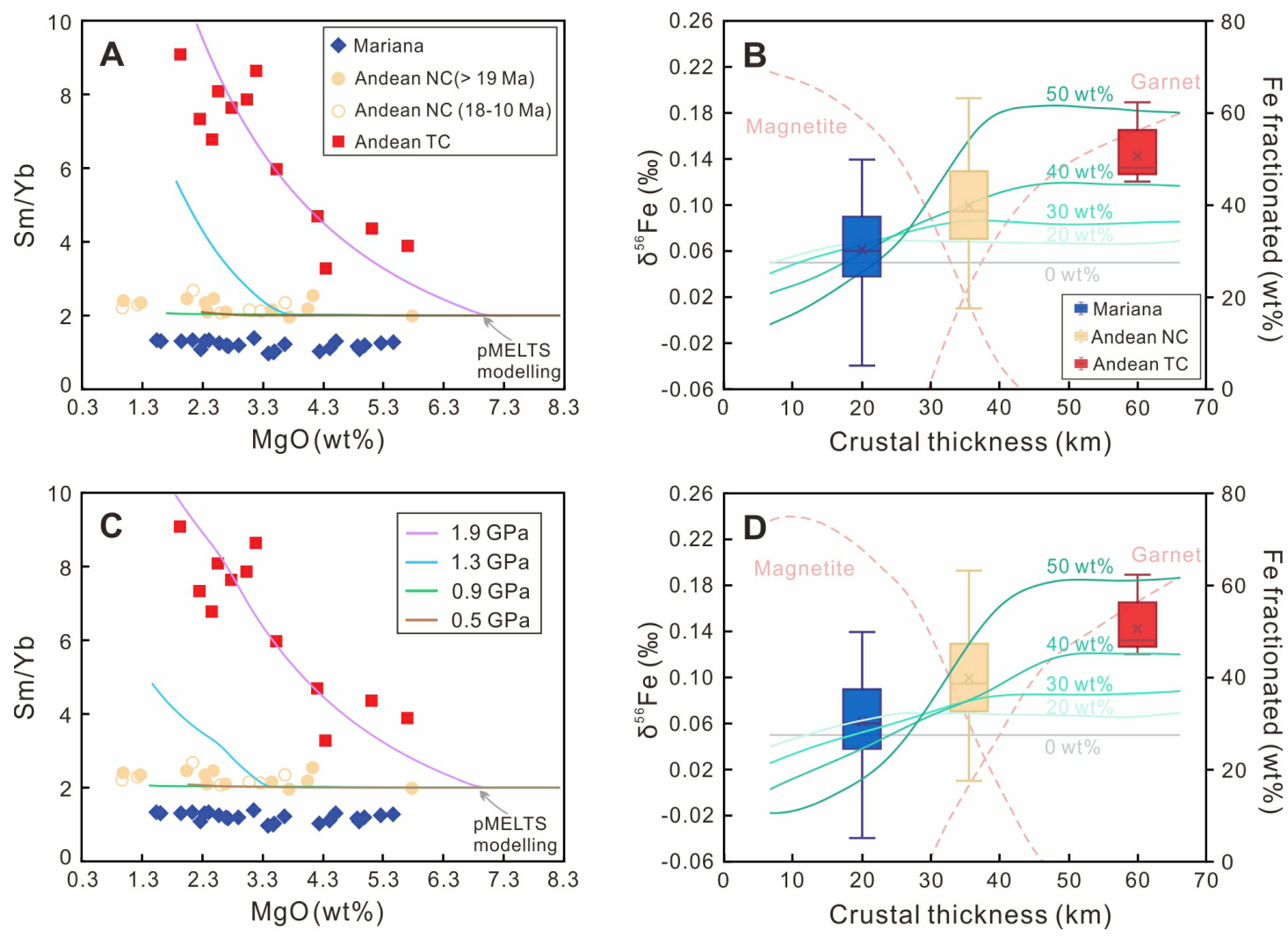

Fig. S1. Modeled pressure effect on melt $\mathrm{Sm} / \mathrm{Yb}(\mathrm{A}, \mathrm{C})$ and $\delta^{56} \mathrm{Fe}(\mathrm{B}, \mathrm{D})$ during arc magma differentiation. The modeling results are from pMELTS simulation of 'Initial Composition A' crystal fractionation under 0.2 to $2.0 \mathrm{GPa}, 3 \mathrm{wt} \%(\mathrm{~A}, \mathrm{~B})$ and $4 \mathrm{wt} \%(\mathrm{C}, \mathrm{D})$ initial water contents, and a constant $f \mathrm{O}_{2}$ of $\mathbf{Q F M}+1$. The pressure can be converted to crustal thickness based on the equation of thickness $(\mathrm{km}) \approx 3.3(\mathrm{~km} / \mathrm{kbar}) \times$ pressure $(\mathrm{kbar})$. The dashed lines in $(\mathrm{B})$ and (D) represent the iron fraction of magnetite/garnet to the bulk cumulate after $50 \mathrm{wt} \%$ crystallization. The solid lines in (B) and (D) are magma $\delta^{56} \mathrm{Fe}$ evolution paths from 0 to $50 \mathrm{wt} \%$ crystallinity. The initial arc melt is assumed to have a $\delta^{56} \mathrm{Fe}$ value of $0.05 \%$ (Foden et al., 2018). 

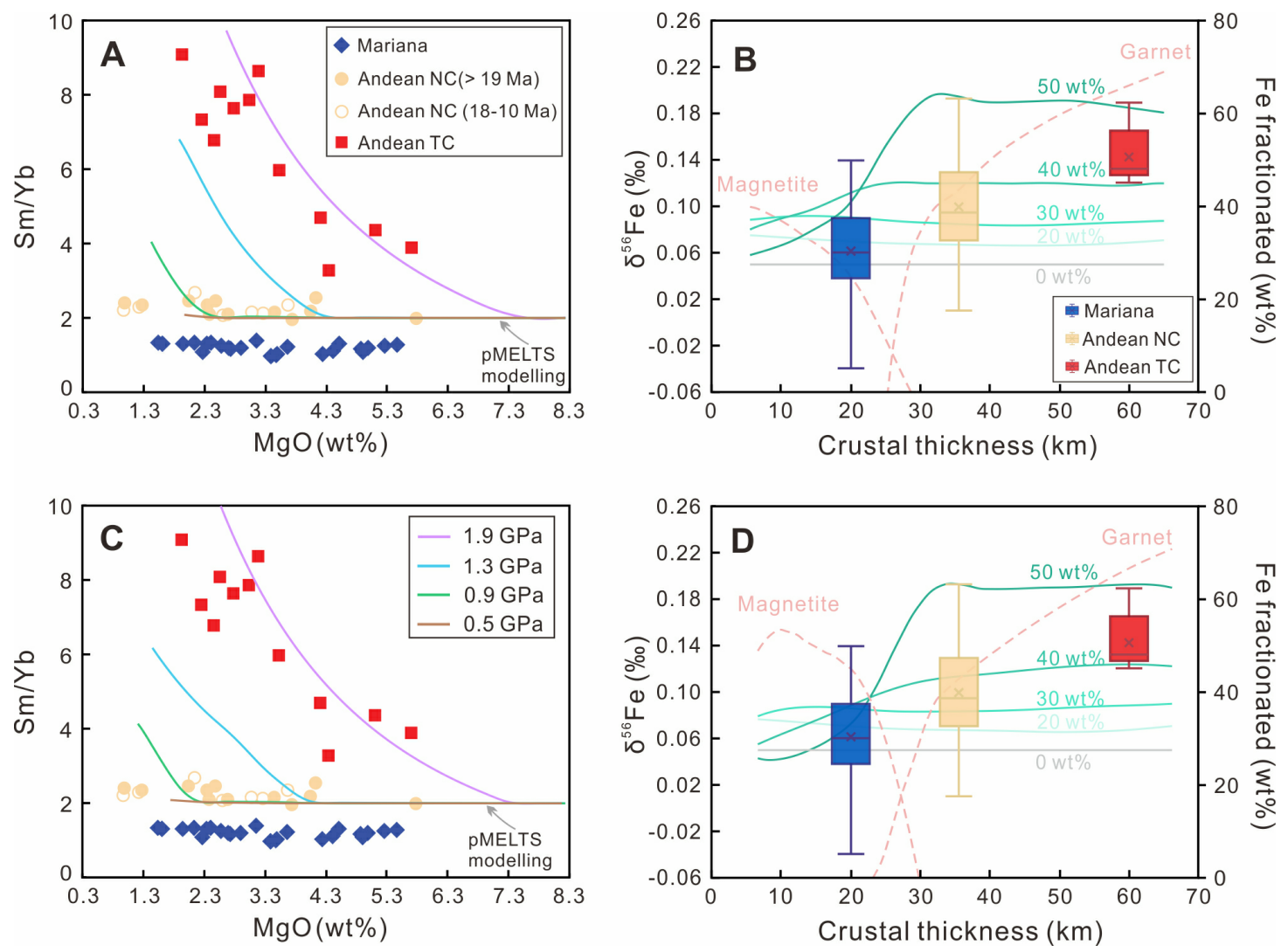

Fig. S2. Modeled pressure effect on melt $\mathrm{Sm} / \mathrm{Yb}(\mathrm{A}, \mathrm{C})$ and $\delta^{56} \mathrm{Fe}(\mathrm{B}, \mathrm{D})$ during arc magma differentiation. The modeling results are from pMELTS simulation of 'Initial Composition A' crystal fractionation under 0.2 to $2.0 \mathrm{GPa}, 3 \mathrm{wt} \%(\mathrm{~A}, \mathrm{~B})$ and $4 \mathrm{wt} \%(\mathrm{C}, \mathrm{D})$ initial water contents, and a constant $f \mathrm{O}_{2}$ of QFM. The dashed lines in (B) and (D) represent the iron fraction of magnetite/garnet to the bulk cumulate after $50 \mathrm{wt} \%$ crystallization. The solid lines in (B) and (D) are magma $\delta^{56} \mathrm{Fe}$ evolution paths from 0 to $50 \mathrm{wt} \%$ crystallinity. The initial arc melt is assumed to have a $\delta^{56} \mathrm{Fe}$ value of $0.05 \%$ (Foden et al., 2018). 

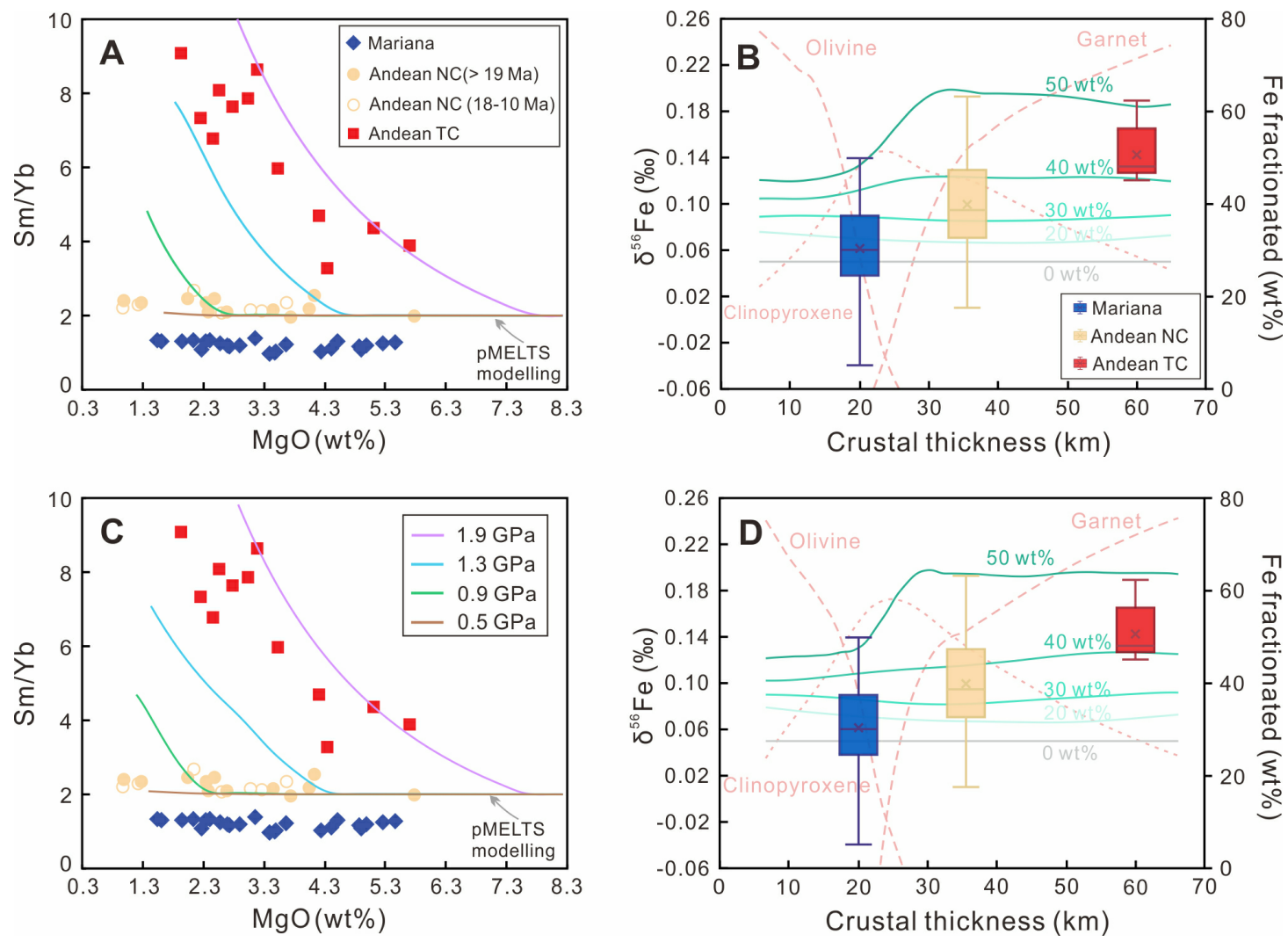

Fig. S3. Modeled pressure effect on melt $\mathrm{Sm} / \mathrm{Yb}(\mathrm{A}, \mathrm{C})$ and $\delta^{56} \mathrm{Fe}(\mathrm{B}, \mathrm{D})$ during arc magma differentiation. The modeling results are from pMELTS simulation of 'Initial Composition A' crystal fractionation under 0.2 to $2.0 \mathrm{GPa}, 3 \mathrm{wt} \%(\mathrm{~A}, \mathrm{~B})$ and $4 \mathrm{wt} \%(\mathrm{C}, \mathrm{D})$ initial water contents, and a constant $f \mathrm{O}_{2}$ of QFM - 1. The dashed lines in (B) and (D) represent the iron fraction of magnetite/clinopyroxene/garnet to the bulk cumulate after $50 \mathrm{wt} \%$ crystallization. The solid lines in (B) and (D) are magma $\delta^{56} \mathrm{Fe}$ evolution paths from 0 to $50 \mathrm{wt} \%$ crystallinity. The initial arc melt is assumed to have a $\delta^{56} \mathrm{Fe}$ value of $0.05 \%$ (Foden et al., 2018). 

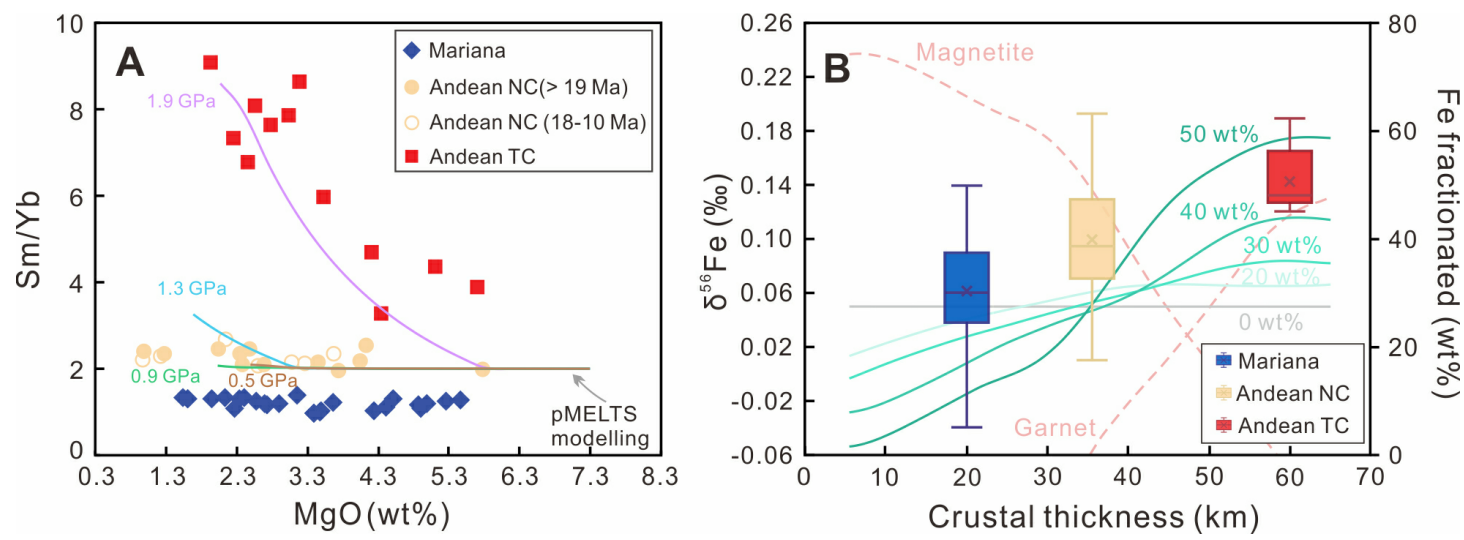

Fig. S4. Modeled pressure effect on melt $\mathrm{Sm} / \mathrm{Yb}(\mathrm{A})$ and $\delta^{56} \mathrm{Fe}$ (B) during arc magma differentiation. The modeling results are from pMELTS simulation of 'Initial Composition B' crystal fractionation under 0.2 to $2.0 \mathrm{GPa}, 3 \mathrm{wt} \%$ initial water content, and a constant $f \mathrm{O}_{2}$ of QFM + 1. The dashed lines in (B) represent the iron fraction of magnetite/garnet to the bulk cumulate after $50 \mathrm{wt} \%$ crystallization. The solid lines in (B) are magma $\delta^{56} \mathrm{Fe}$ evolution paths from 0 to $50 \mathrm{wt} \%$ crystallinity. The initial arc melt is assumed to have a $\delta^{56} \mathrm{Fe}$ value of $0.05 \%$ (Foden et al., 2018).
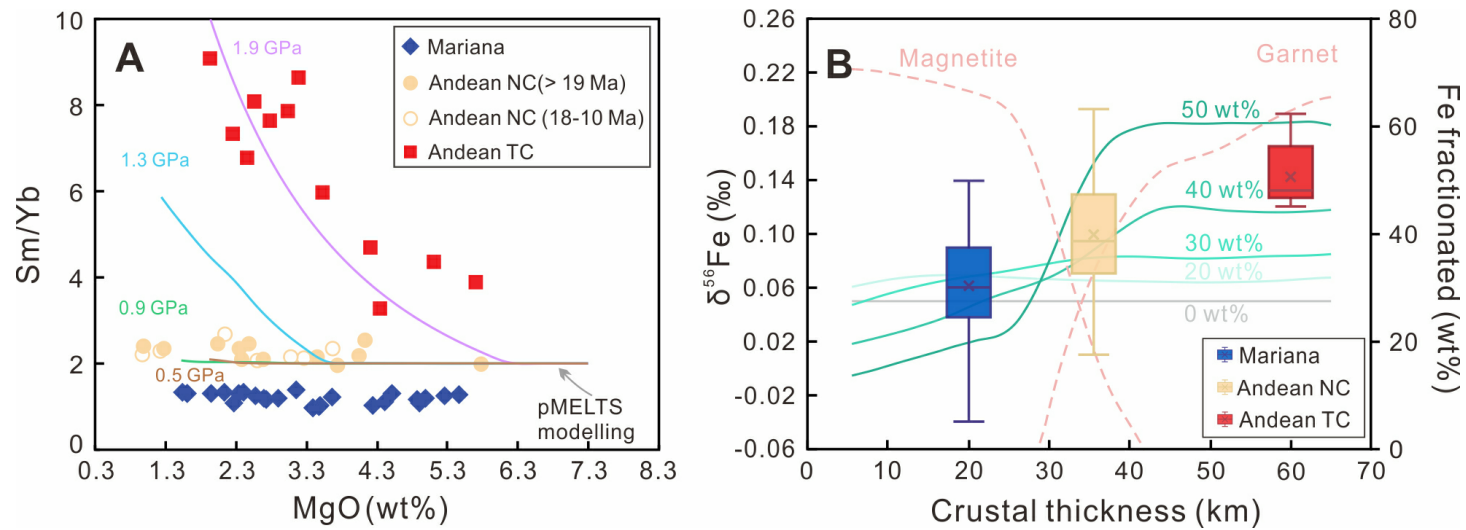

Fig. S5. Modeled pressure effect on melt $\mathrm{Sm} / \mathrm{Yb}$ (A) and $\delta^{56} \mathrm{Fe}$ (B) during arc magma differentiation. The modeling results are from pMELTS simulation of 'Initial Composition B' crystal fractionation under 0.2 to $2.0 \mathrm{GPa}, 3 \mathrm{wt} \%$ initial water content, and a constant $f \mathrm{O}_{2}$ of QFM. The dashed lines in (B) represent the iron fraction of magnetite/garnet to the bulk cumulate after $50 \mathrm{wt} \%$ crystallization. The solid lines in (B) are magma $\delta^{56} \mathrm{Fe}$ evolution paths from 0 to $50 \mathrm{wt} \%$ crystallinity. The initial arc melt is assumed to have a $\delta^{56} \mathrm{Fe}$ value of $0.05 \%$ (Foden et al., 2018). 

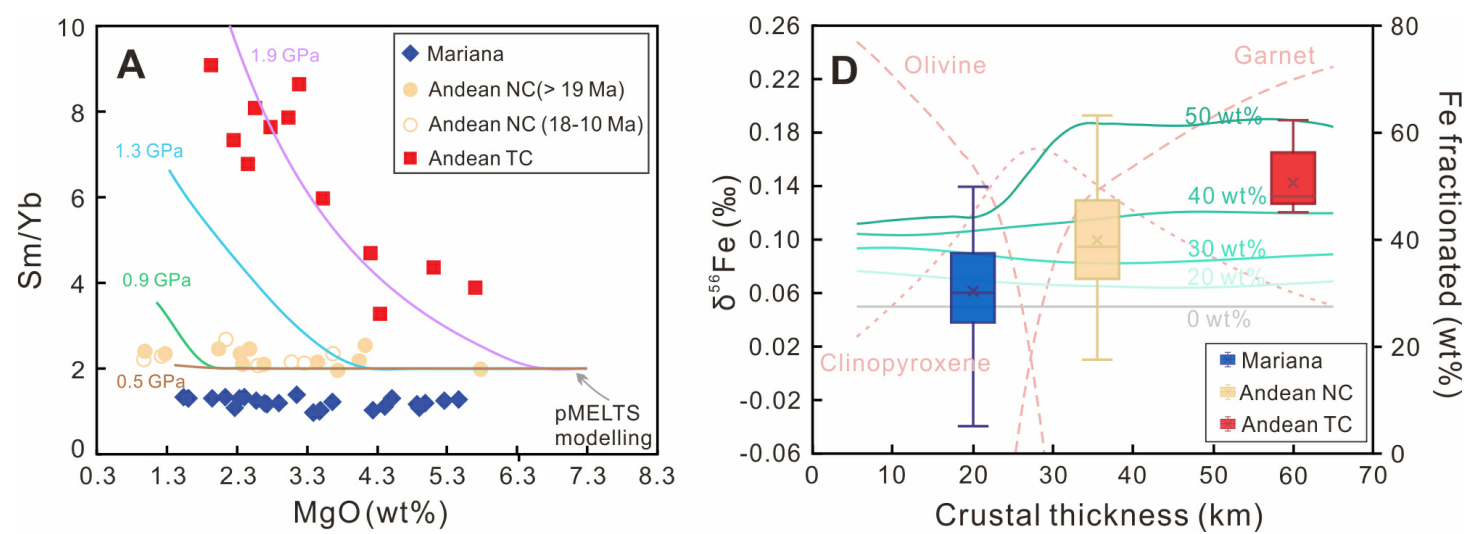

Fig. S6. Modeled pressure effect on melt $\mathrm{Sm} / \mathrm{Yb}$ (A) and $\delta^{56} \mathrm{Fe}$ (B) during arc magma differentiation. The modeling results are from pMELTS simulation of 'Initial Composition B' crystal fractionation under 0.2 to $2.0 \mathrm{GPa}, 3 \mathrm{wt} \%$ initial water content, and a constant $f \mathrm{O}_{2}$ of QFM - 1. The dashed lines in (B) represent the iron fraction of olivine/clinopyroxene/garnet to the bulk cumulate after $50 \mathrm{wt} \%$ crystallization. The solid lines in (B) are magma $\delta^{56} \mathrm{Fe}$ evolution paths from 0 to $50 \mathrm{wt} \%$ crystallinity. The initial arc melt is assumed to have a $\delta^{56} \mathrm{Fe}$ value of $0.05 \%$ (Foden et al., 2018).
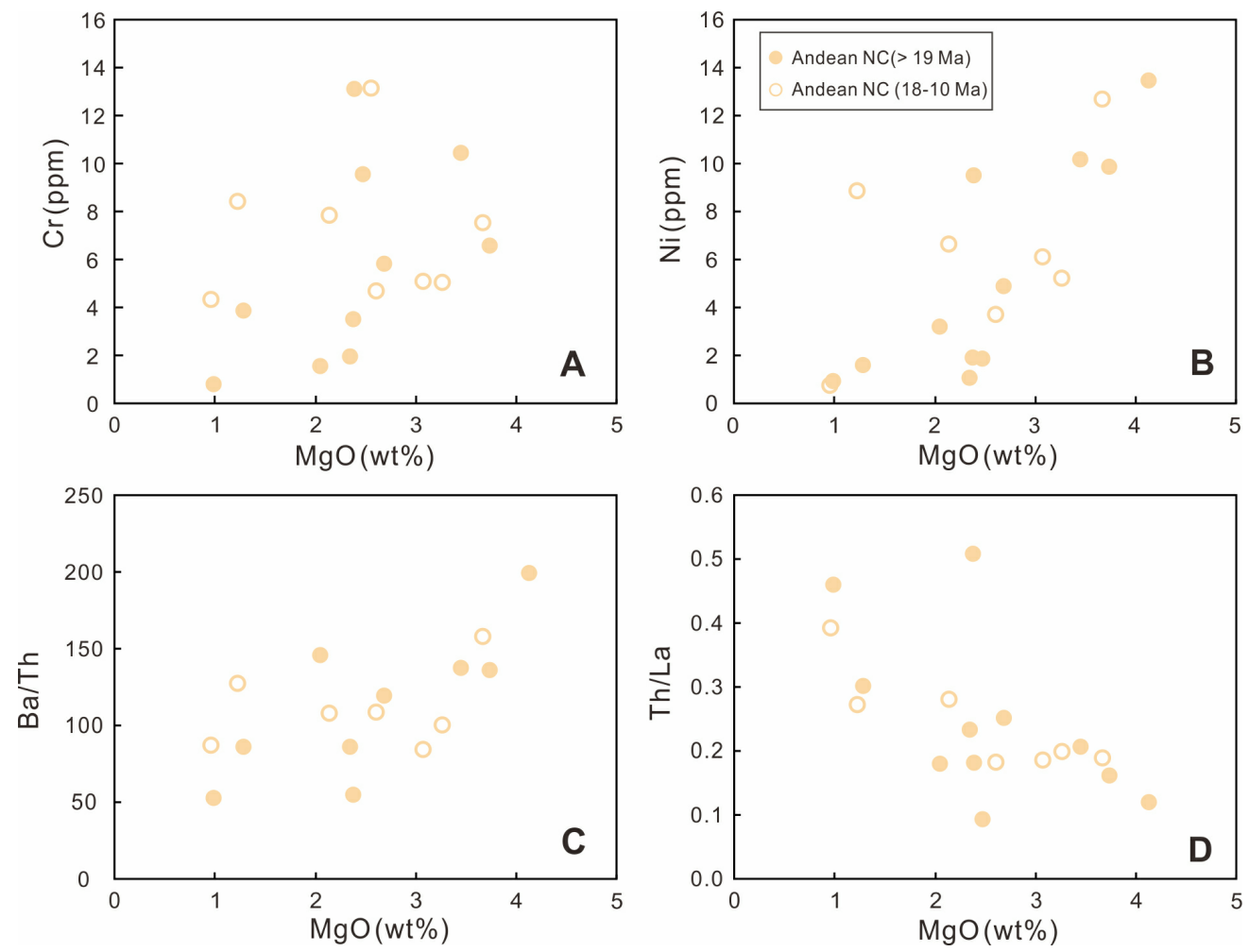

Fig. S7. A-D show $\mathrm{Cr}(\mathrm{ppm}), \mathrm{Ni}(\mathrm{ppm}), \mathrm{Ba} / \mathrm{Th}$ and $\mathrm{Th} / \mathrm{La}$ versus $\mathrm{MgO}$ (wt\%) for the Andean "Normal Crust" samples. 


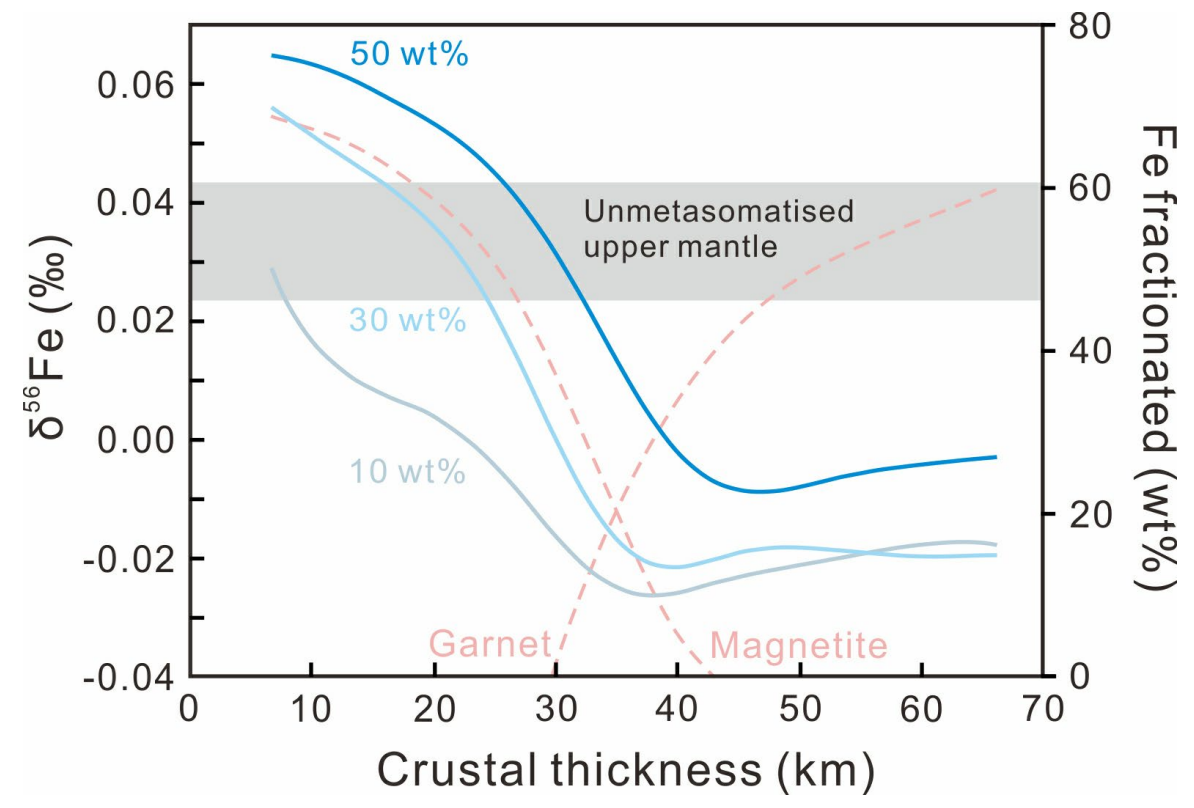

Fig. S8. Modeled pressure effect on cumulate $\delta^{56} \mathrm{Fe}$ during arc magma differentiation. The modeling results are from pMELTS simulation of 'Initial Composition A' crystal fractionation under 0.2 to $2.0 \mathrm{GPa}, 3 \mathrm{wt} \%$ initial water content, and a constant $f \mathrm{O}_{2}$ of $\mathbf{Q F M}+\mathbf{1}$. The dashed lines represent the iron fraction of magnetite/garnet to the bulk cumulate after $50 \mathrm{wt} \%$ crystallization. The solid lines are cumulate $\delta^{56} \mathrm{Fe}$ evolution paths from 10 to $50 \mathrm{wt} \%$ crystallinity. The initial arc melt is assumed to have a $\delta^{56} \mathrm{Fe}$ value of $0.05 \%$ (Foden et al., 2018). The shaded area represents the mean $\delta^{56} \mathrm{Fe}$ of unmetasomatised upper mantle lherzolite $\left(\delta^{56} \mathrm{Fe}\right.$ $=0.033 \pm 0.01,2 \mathrm{SE}$; Sossi et al., 2016).

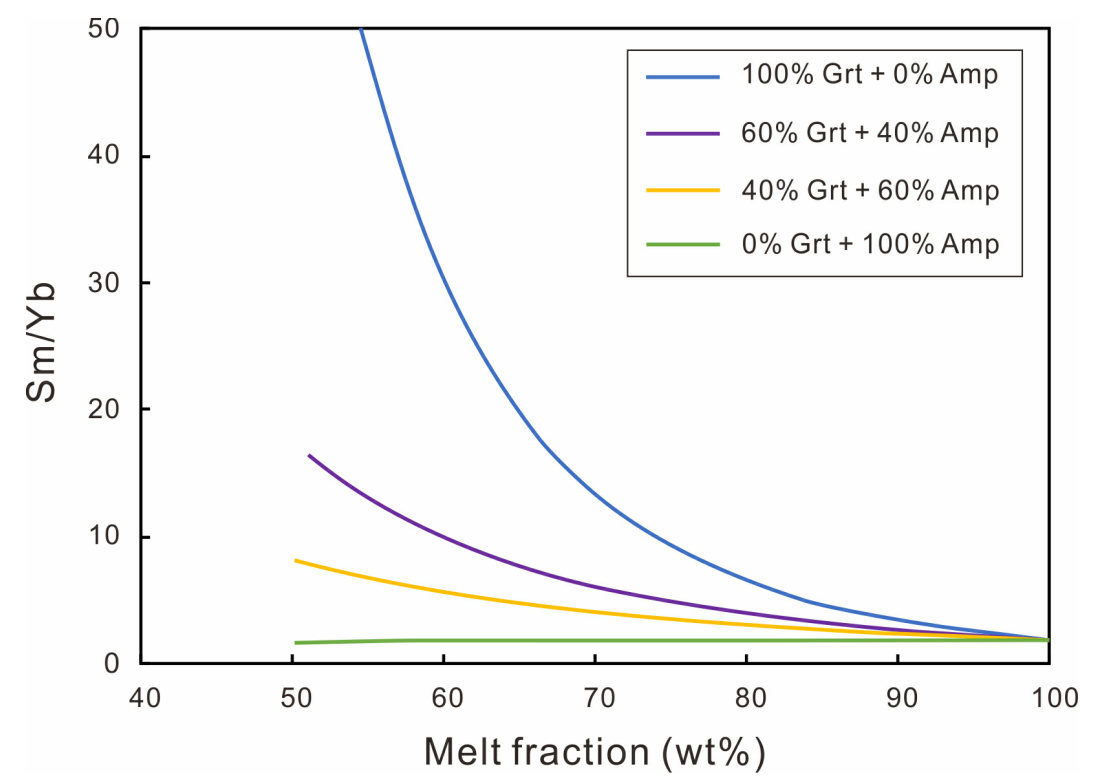

Fig. S9 Effect of amphibole/garnet fractionation on the residual magma's $\mathrm{Sm} / \mathrm{Yb}$ ratio. The partition coefficients for different minerals used in the modeling are given in Table S2. 
Table S1 Compilation of published mineral/melt-magnetite fractionation factors

\begin{tabular}{|c|c|c|c|c|c|c|c|c|c|c|c|}
\hline Type & Phase A & $\mathrm{Fe}^{3+} / \Sigma \mathrm{Fe}$ & $\mathbf{C N}$ & $10^{3} \ln \beta^{56} \mathrm{Fe}$ & Phase B & $\mathrm{Fe}^{3+} / \Sigma \mathrm{Fe}$ & $\mathbf{C N}$ & $10^{3} \ln \beta^{56} \mathrm{Fe}$ & $\Delta^{56} \mathrm{Fe}_{\mathrm{A}-\mathrm{B}}$ & $\begin{array}{c}\text { Temperature } \\
(\mathbf{K})\end{array}$ & Reference \\
\hline Rock-calibrated & Grt & & & & Mag & & & & -0.36 & $10^{6} / \mathrm{T}^{2}$ & Ye et al., 2020 \\
\hline Experimental & Grt & & & & Mag & & & & -0.44 & $10^{6} / \mathrm{T}^{2}$ & Sossi and O'Neill, 2017 \\
\hline Theoretical & Andesitic & 0.05 & $5-6$ & 0.57 & Mag & 0.67 & 5.33 & 0.75 & -0.19 & $10^{6} / \mathrm{T}^{2}$ & Dauphas et al., 2014 \\
\hline Theoretical & melt & 0.35 & $5-6$ & 0.73 & Mag & 0.67 & 5.33 & 0.75 & -0.02 & $10^{6} / \mathrm{T}^{2}$ & Dauphas et al., 2014 \\
\hline Rock-calibrated & Melt & & & & Mag & & & & -0.13 & $10^{6} / \mathrm{T}^{2}$ & Sossi et al., 2012 \\
\hline Theoretical & $\mathrm{Ol}$ & 0 & 6 & 0.56 & Mag & 0.67 & 5.33 & 0.75 & -0.19 & $10^{6} / \mathrm{T}^{2}$ & Dauphas et al., 2014 \\
\hline Experimental & $\mathrm{Fa}$ & & & & Mag & & & & -0.20 & $10^{6} / \mathrm{T}^{2}$ & Shahar et al., 2008 \\
\hline Theoretical & Opx & 0 & 6 & 0.49 & Mag & 0.67 & 5.33 & 0.75 & -0.27 & $10^{6} / \mathrm{T}^{2}$ & Dauphas et al., 2012 \\
\hline Rock-calibrated & Px & & & & Mag & & & & -0.30 & $10^{6} / \mathrm{T}^{2}$ & Sossi et al., 2012 \\
\hline Theoretical & Amp & 0.36 & 6 & 0.54 & Mag & 0.67 & 5.33 & 0.75 & -0.20 & $10^{6} / \mathrm{T}^{2}$ & Schoenberg et al., 2009 \\
\hline Rock-calibrated & Amp & & & & Mag & & & & -0.16 & $10^{6} / \mathrm{T}^{2}$ & Ye et al., 2020 \\
\hline Calculated & Grt & & & & Melt & & & & -0.23 & $10^{6} / \mathrm{T}^{2}$ & \\
\hline Calculated & Mag & & & & Melt & & & & 0.13 & $10^{6} / \mathrm{T}^{2}$ & \\
\hline Calculated & $\mathrm{Fa}$ & & & & Melt & & & & -0.07 & $10^{6} / \mathrm{T}^{2}$ & \\
\hline Calculated & Px & & & & Melt & & & & -0.17 & $10^{6} / \mathrm{T}^{2}$ & \\
\hline Calculated & Amp & & & & Melt & & & & -0.03 & $10^{6} / \mathrm{T}^{2}$ & \\
\hline
\end{tabular}

Note: The $10^{3} \ln \beta^{56} \mathrm{Fe}$ for magnetite is from Roskosz et al (2015) and the equilibrium fractionation factor between $\mathrm{A}$ and $\mathrm{B}$ is calculated as: $\Delta^{56} \mathrm{Fe}_{\mathrm{A}-\mathrm{B}}=10^{3} \ln \beta^{56} \mathrm{Fe}_{\mathrm{A}}-$ $10^{3} \ln \beta^{56} \mathrm{Fe}_{\mathrm{A}}$. The calculated mineral-melt $\mathrm{Fe}$ isotope fractionation factors are derived by the equation of $\Delta^{56} \mathrm{Fe}_{\text {mineral-melt }}=\Delta^{56} \mathrm{Fe}_{\text {mineral-Mag }}+\Delta^{56} \mathrm{Fe}_{\text {Mag-melt }}$ based on the factors constrained by natural rocks (except for $\Delta^{56} \mathrm{Fe} \mathrm{Fa}_{\mathrm{Mag}}$, which is constrained by experiment), in which $\Delta^{56} \mathrm{Fe}_{\mathrm{melt}-\mathrm{Mag}}$ is cited as $0.13 \times 10^{6} / \mathrm{T}^{2}$ (Sossi et al., 2012 ). $\mathrm{CN}=$ coordination. Abbreviations: $\mathrm{Grt}=$ garnet $\mathrm{Ol}=$ olivine, $\mathrm{Fa}=$ fayalite, $\mathrm{Opx}=$ orthopyroxene, $\mathrm{Px}=$ pyroxene, Amp $=$ amphibole, Mag $=$ magnetite. 
Table S2 Mineral/melt partition coefficients used in the trace element modeling

\begin{tabular}{|l|c|c|c|c|}
\hline \multicolumn{1}{|c|}{ Mineral } & Element & Kd value & Kd type & Reference \\
\hline Garnet & $\mathrm{Yb}$ & 6.1 & Experimental & Green et al., 2000 \\
\hline Clinopyroxene & $\mathrm{Yb}$ & 0.54 & Phenocryst-matrix & Dostal et al., 1983 \\
\hline Orthopyroxene & $\mathrm{Yb}$ & 0.22 & Experimental & Green et al., 2000 \\
\hline Biotite & $\mathrm{Yb}$ & 0.44 & Phenocryst-matrix & Higuchi and Nagasawa, 1969 \\
\hline Plagioclase & $\mathrm{Yb}$ & 0.299 & Phenocryst-matrix & Schnetzler and Philpotts, 1970 \\
\hline Magnetite & $\mathrm{Yb}$ & 0.24 & Phenocryst-matrix & Luhr and Carmichael, 1980 \\
\hline Olivine & $\mathrm{Yb}$ & 0.03 & Phenocryst-matrix & Luhr and Carmichael, 1980 \\
\hline Amphibole & $\mathrm{Yb}$ & 0.44 & Experimental & Adam and Green, 2006 \\
\hline Garnet & $\mathrm{Sm}$ & 0.800 & Experimental & Ronov and Yaroshevskiy, \\
\hline Clinopyroxene & $\mathrm{Sm}$ & 0.550 & Phenocryst-matrix & Dostal et al., 1983 \\
\hline Orthopyroxene & $\mathrm{Sm}$ & 0.015 & Experimental & Green et al., 2000 \\
\hline Biotite & $\mathrm{Sm}$ & 0.26 & Phenocryst-matrix & Higuchi and Nagasawa, 1969 \\
\hline Plagioclase & $\mathrm{Sm}$ & 0.203 & Phenocryst-matrix & Schnetzler and Philpotts, 1970 \\
\hline Magnetite & $\mathrm{Sm}$ & 0.290 & Phenocryst-matrix & Luhr and Carmichael, 1980 \\
\hline Olivine & $\mathrm{Sm}$ & 0.007 & Phenocryst-matrix & Dunn and Sen, 1994 \\
\hline Amphibole & $\mathrm{Sm}$ & 0.54 & Experimental & Adam and Green, 2006 \\
\hline
\end{tabular}




\section{References in the supplementary file}

Adam, J., Green, T., 2006, Trace element partitioning between mica-and amphibole-bearing garnet lherzolite and hydrous basanitic melt: 1. Experimental results and the investigation of controls on partitioning behavior: Contributions to Mineralogy and Petrology, v. 152, p. $1-17$.

Beard, B.L., Johnson, C.M., Skulan, J.L., Nealson, K.H., Cox, L., and Sun, H., 2003, Application of $\mathrm{Fe}$ isotopes to tracing the geochemical and biological cycling of Fe: Chemical Geology, v. 195, p. 87-117.

Craddock, P.R., and Dauphas, N., 2011, Iron isotopic compositions of geological reference materials and chondrites: Geostandards and Geoanalytical Research, v. 35, p. 101-123.

Dauphas, N., Roskosz, M., Alp, E.E., Golden, D.C., Sio, C.K., Tissot, F.L.H., Hu, M.Y., Zhao, J., Gao, L., and Morris, R.V., 2012, A general moment NRIXS approach to the determination of equilibrium $\mathrm{Fe}$ isotopic fractionation factors: application to goethite and jarosite: Geochimica et Cosmochimica Acta, v. 94, p. 254-275.

Dauphas, N., Roskosz, M., Alp, E.E., Neuville, D.R., Hu, M.Y., Sio, C.K., Tissot, F.L.H., Zhao, J., Tissandier, L., Médard, E., and Cordier, C., 2014, Magma redox and structural controls on iron isotope variations in Earth's mantle and crust: Earth and Planetary Science Letters, v. 398, p. $127-140$.

Dostal, J., Dupuy, C., Carron, J. P., De Kerneizon, M. L.G., and Maury, R.C., 1983, Partition coefficients of trace elements: application to volcanic rocks of St. Vincent, West Indies: Geochimica et Cosmochimica Acta, v. 47, p. 525-533.

Du, D.H., Wang, X.L., Yang, T., Chen, X., Li, J.Y., and Li, W., 2017, Origin of heavy Fe isotope compositions in high-silica igneous rocks: a rhyolite perspective: Geochimica et Cosmochimica Acta, v. 218, p. 58-72.

Dunn, T., and Sen, C., 1994, Mineral/matrix partition coefficients for orthopyroxene, plagioclase, and olivine in basaltic to andesitic systems: a combined analytical and experimental study: Geochimica et Cosmochimica Acta, v. 58, p. 717--733.

Foden, J., Sossi, P.A., and Nebel, O., 2018, Controls on the iron isotopic composition of global arc magmas: Earth and Planetary Science Letters, v. 494, p. 190-201.

Ghiorso, M.S., Hirschmann, M.M., Reiners, P.W., and Kress, V.C., III, 2002, The pMELTS: A revision of MELTS for improved calculation of phase relations and major element partitioning related to partial melting of the mantle to $3 \mathrm{GPa}$ : Geochemistry Geophysics Geosystems, v. 3, p. 1-35.

Green, T.H., Blundy, J.D., Adam, J., and Yaxley, G.M., 2000, SIMS determination of trace element partition coefficients between garnet, clinopyroxene and hydrous basaltic liquids at 2-7.5 GPa and 1080-1200 C: Lithos, v. 53, p. 165-187. 
He, Y., Ke, S., Teng, F.Z., Wang, T., Wu, H., Lu, Y., and Li, S., 2015, High-precision iron isotope analysis of geological reference materials by high-resolution MC-ICP-MS: Geostandards and Geoanalytical Research, v. 39, p. 341-356.

Heimann, A., Beard, B.L., and Johnson, C.M., 2008, The role of volatile exsolutions and subsolidus fluid/rock interactions in producing high ${ }^{56} \mathrm{Fe} /{ }^{54} \mathrm{Fe}$ ratios in siliceous igneous rocks: Geochimica et Cosmochimica Acta, v. 72, p. 4379-4396.

Higuchi, H., and Nagasawa, H., 1969, Partition of trace elements between rock-forming minerals and the host volcanic rocks.: Earth and Planetary Science Letters, v. 7, p. 281287.

Huang, Q., Viehmann, S., Walde, D. H., and Li, W., 2021, Iron isotope constraints on the metal source and depositional environment of the Neoproterozoic banded iron-and manganese deposits in Urucum, Brazil: Geochemistry, 125771.

Kay, S.M., and Mpodozis, C., 2001, Central Andean ore deposits linked to evolving shallow subduction systems and thickening crust: Geological Society of America Today, v. 11, p. 49.

Kay, S.M., Mpodozis, C., and Gardeweg, M., 2013, Magma sources and tectonic setting of Central Andean andesites $\left(25.5-28^{\circ} \mathrm{S}\right)$ related to crustal thickening, forearc subduction erosion and delamination: Geological Society, London, Special Publications, v. 385, p. $303-334$

Kay, S.M., Mpodozis, C., Ramos, V.A., and Munizaga, F., 1991, Magma source variations for mid-late Tertiary magmatic rocks associated with a shallowing subduction zone and a thickening crust in the central Andes ( 28 to $33^{\circ} \mathrm{S}$ ): Geological Society of America Special Paper, v. 265, p. 113-137.

Luhr, J.F., and Carmichael, I.S., 1980, The colima volcanic complex, Mexico: Contributions to Mineralogy and Petrology, v. 71, p. 343-372.

Philpotts, J.A., and Schnetzler, C.C., 1970, Apollo 11 lunar samples: K, Rb, Sr, Ba and rareearth concentrations in some rocks and separated phases: Geochimica et Cosmochimica Acta Supplement, v. 1, p. 1471.

Ronov, A.B., and Yaroshevsky, A.A., 1976, A new model of chemical composition of the Earth crust: Geokhimiya, v. 12, p. 1763.

Schmidt, M.W., and Jagoutz, O., 2017, The global systematics of primitive arc melts: Geochemistry, Geophysics, Geosystems, v. 18, p. 2817-2854.

Schoenberg, R., Marks, M.A., Schuessler, J.A., von Blanckenburg, F., and Mark1, G., 2009, Fe isotope systematics of coexisting amphibole and pyroxene in the alkaline igneous rock suite of the Ilímaussaq Complex, South Greenland: Chemical Geology, v. 258, p. 65-77. Beard, B.L., Johnson, C.M., Skulan, J.L., Nealson, K.H., Cox, L., and Sun, H., 2003, Application of $\mathrm{Fe}$ isotopes to tracing the geochemical and biological cycling of $\mathrm{Fe}$ : 
Chemical Geology, v. 195, p. 87-117.

Shahar, A., Young, E.D., and Manning, C.E., 2008, Equilibrium high-temperature Fe isotope fractionation between fayalite and magnetite: an experimental calibration: Earth and Planetary Science Letters, v. 268, p. 330-338.

Sossi, P.A., and O'Neill, H.S.C., 2017, The effect of bonding environment on iron isotope fractionation between minerals at high temperature: Geochimica et Cosmochimica Acta, v. 196, p. 121-143.

Sossi, P.A., Foden, J.D., and Halverson, G.P., 2012, Redox-controlled iron isotope fractionation during magmatic differentiation: an example from the Red Hill intrusion, S. Tasmania: Contributions to Mineralogy and Petrology, v. 164, p. 757-772.

Sossi, P.A., Nebel, O., and Foden, J., 2016, Iron isotope systematics in planetary reservoirs: Earth and Planetary Science Letters, v. 452, p. 295-308.

Tang, M., Erdman, M., Eldridge, G., and Lee, C.-T.A., 2018, The redox "filter" beneath magmatic orogens and the formation of continental crust: Science Advances, v. 4, p. eaar4444.

Weyer, S., and Ionov, D.A., 2007, Partial melting and melt percolation in the mantle: the message from Fe isotopes: Earth and Planetary Science Letters, v. 259, p. 119-133.

Williams, H.M., Prytulak, J., Woodhead, J.D., Kelley, K.A., Brounce, M., and Plank, T., 2018, Interplay of crystal fractionation, sulfide saturation and oxygen fugacity on the iron isotope composition of arc lavas: an example from the Marianas: Geochimica et Cosmochimica Acta, v. 226, p. 224-243.

Ye, H., Wu, C.Z., Yang, T., Santosh, M., Yao, X.Z., Gao, B.F., Wang, X.L., and Li, W., 2017, Updating the geologic barcodes for south China: discovery of late archean banded iron formations in the Yangtze craton: Scientific Report, v. 7, p. 15082.

Ye, H., Wu, C., Brzozowski, M.J., Yang, T., Zha, X., Zhao, S., Gao, B., and Li, W., 2020, Calibrating equilibrium $\mathrm{Fe}$ isotope fractionation factors between magnetite, garnet, amphibole, and biotite: Geochimica et Cosmochimica Acta, v. 271, p. 78-95.

Zimmer, M.M., Plank, T., Hauri, E.H., Yogodzinski, G.M., Stelling, P., Larsen, J., Singer, B., Jicha, B., Mandeville, C., and Nye, C.J., 2010, The role of water in generating the calcalkaline trend: new volatile data for Aleutian magmas and a new tholeiitic index: Journal of Petrology, v. 51, p. 2411-2444. 